\title{
MAPK- and AKT-activated thyroid cancers are sensitive to group I PAK inhibition
}

\author{
Christina M Knippler¹, Motoyasu Saji1, Neel Rajan², Kyle Porter³, Krista M D La Perle ${ }^{4}$ and Matthew D Ringel1 \\ ${ }^{1}$ Division of Endocrinology, Diabetes, and Metabolism, The Ohio State University Wexner Medical Center and Arthur G. James Comprehensive Cancer \\ Center, Columbus, Ohio, USA \\ ${ }^{2}$ College of Arts and Sciences, The Ohio State University, Columbus, Ohio, USA \\ ${ }^{3}$ Center for Biostatistics, Department of Biomedical Informatics, The Ohio State University, Columbus, Ohio, USA \\ ${ }^{4}$ Department of Veterinary Biosciences, Comparative Pathology \& Mouse Phenotyping Shared Resource, The Ohio State University, Columbus, Ohio, USA
}

Correspondence should be addressed to M D Ringel: matthew.ringel@osumc.edu

\begin{abstract}
The number of individuals who succumb to thyroid cancer has been increasing and those who are refractory to standard care have limited therapeutic options, highlighting the importance of developing new treatments for patients with aggressive forms of the disease. Mutational activation of MAPK signaling, through BRAF and RAS mutations and/or gene rearrangements, and activation of PI3K signaling, through mutational activation of PIK3CA or loss of PTEN, are well described in aggressive thyroid cancer. We previously reported overactivation and overexpression of p21-activated kinases (PAKs) in aggressive human thyroid cancer invasive fronts and determined that PAK1 functionally regulated thyroid cancer cell migration. We reported mechanistic crosstalk between the MAPK and PAK pathways that are BRAF-dependent but MEK independent, suggesting that PAK and MEK inhibition might be synergistic. In the present study, we tested this hypothesis. Pharmacologic inhibition of group I PAKs using two PAK kinase inhibitors, G-5555 or FRAX1036, reduced thyroid cancer cell viability, cell cycle progression and migration and invasion, with greater potency for G-5555. Combination of G-5555 with vemurafenib was synergistic in BRAFV600E-mutated thyroid cancer cell lines. Finally, G-5555 restrained thyroid size of BRAFV600E-driven murine papillary thyroid cancer by $>50 \%$ $(P<0.0001)$ and reduced carcinoma formation $(P=0.0167)$, despite maintenance of MAPK activity. Taken together, these findings suggest both that group I PAKs may be a new therapeutic target for thyroid cancer and that PAK activation is functionally important for BRAFV600E-mediated thyroid cancer development.
\end{abstract}
Key Words
- thyroid cancer
- p21-activated kinase
- BRAF
- cancer therapeutics

\section{Introduction}

The National Cancer Institute estimated 53,990 new cases of thyroid cancer in the United States in 2018 and 2060 patients were expected to die from the disease (Noone et al. 2018). Although most thyroid cancers are curable, aggressive tumors rarely respond to standard therapy, including thyroidectomy, radioiodine therapy and thyroid-stimulating hormone (TSH) suppression. Thus, individuals with these tumors have a poor prognosis and, until recently, no further treatments were FDA approved. Over the past decade, advances in defining the molecular underpinnings of aggressive thyroid cancer have resulted in clinical trials and FDA approvals of compounds targeting either the tumor microenvironment or 'genetic drivers' (Haraldsdottir \& Shah 2014). Unfortunately, these 
treatments only delay disease progression and/or induce transient partial remissions, highlighting the importance of new research in this area.

Genetic alterations that result in enhanced activation of the MAPK and AKT pathways occur frequently in thyroid cancers. The most common form of thyroid cancer, well-differentiated papillary thyroid cancer (PTC), is driven primarily by mutually exclusive mutations that activate MAPK signaling; $\sim 60 \%$ have BRAFv600E mutations, $15 \%$ have RAS mutations and 12\% have gene rearrangements (such as RET/PTC) (Fagin \& Wells 2016). By contrast, follicular thyroid cancers (FTCs) are largely driven by activation of PI3K signaling and MAPK activation, with a high frequency of activated RAS (NRAS) mutations, PTEN loss, PIK3CA mutations or PAX8-PPAR $\gamma$ fusions. Anaplastic thyroid cancers (ATCs) have the worst prognosis, with a mean survival of only 6 months, and often have mutational activation of both PI3K and MAPK pathways along with mutations in TP53, TERT promoter and/or epigenetic regulatory genes (Fagin \& Wells 2016). There has been particular interest in targeting BRAFV600E because of its high frequency in thyroid cancer overall, its enrichment in clinical trial populations and the availability of highly specific inhibitors.

Vemurafenib and dabrafenib are selective inhibitors of BRAFV600E that potently inhibit MEK and ERK activation by BRAFV600E (Joseph et al. 2010). Clinical trials showed remarkable short-term efficacy in BRAF-mutated melanomas and led to FDA approvals for patients with this cancer (Chapman et al. 2011, Hauschild et al. 2012). Similar results have been reported for BRAFV600E-mutated PTC (Falchook et al. 2015, Brose et al. 2016). However, for both melanoma and PTC, while the initial responses are often dramatic, acquired resistance is nearly universal. In PTC, mechanisms of resistance include increased expression and activation of HER3 (Montero-Conde et al. 2013), upregulation of c-MET (Byeon et al. 2016, 2017, Knauf et al. 2018) and acquired mutations in RAS genes (Ofir Dovrat et al. 2018).

Group I PAKs are a family of kinases that are activated by the small Rho GTPases, RAC1 and CDC42, and signal to regulate cell motility and oncogenic growth-activating pathways, including MAPK and AKT (Manser et al. 1994, Higuchi et al. 2008, Wang et al. 2013, Radu et al. 2014). We recently identified a novel role for group I PAKs, specifically PAK1, in thyroid cancer. Initial experiments using an unbiased mRNA microarray and subsequent validation with immunohistochemistry identified PAK activation in the invasive fronts of aggressive human PTCs (Vasko et al. 2007, McCarty et al. 2010).
Subsequent studies demonstrated that upon induction of BRAFV600E in mouse thyroids, PTCs develop and group I PAK expression and activity increased (McCarty et al. 2014). We further determined that PAK activation in thyroid cells requires BRAF expression and that they co-localize. Unexpectedly, BRAF-mediated PAK activity was independent of MEK activity or expression, despite known crosstalk between PAK and MEK/ERK. Finally, BRAF, PAK1 and MEK coordinately regulate thyroid cancer cell motility, suggesting complex but not entirely overlapping signaling pathways (McCarty et al. 2014). These data were subsequently supported in melanoma and colon cancer cells, suggesting a generalized signaling interaction (Babagana et al. 2017).

PI3K activation also is common in thyroid cancer, particularly in FTC, in the invasive fronts of aggressive PTCs, and as secondary events in dedifferentiated thyroid cancer (Shinohara et al. 2007, Vasko et al. 2007, Xing 2010). The causes include genetic/epigenetic loss of PTEN expression, activating mutations in the catalytic subunit of PI3K and activation by upstream receptors (Xing 2010). Group I PAKs facilitate PI3K signaling by scaffolding both PDK1 and AKT (Higuchi et al. 2008). Thus, in addition to facilitating MAPK signaling, PAK also enhances AKT activation.

In addition to our work in thyroid cancer, PAK is an important regulator of cancer progression in a number of other cancer types, including melanoma and breast cancer (Ong et al. 2013, 2015). For example, PAK activation, in some cases driven by RAC1 mutations, has also been implicated as a mechanism of primary resistance to BRAF and MEK inhibitors in melanoma (Babagana et al. 2017, Lu et al. 2017). Together, these data suggest an important role for PAK in MAPK-regulated cancers and underscore its potential to be translated into therapeutic targeting.

Several PAK inhibitors have been developed with varied efficacy (Semenova \& Chernoff 2017). Two of the most selective ATP-competitive group I PAK inhibitors are FRAX1036 (Chow et al. 2015, Ong et al. 2015) and its derivative, G-5555 (Ndubaku et al. 2015, Rudolph et al. 2016). G-5555 showed promising results in preclinical models of breast and lung cancers, but its effectiveness in thyroid cancer or in the context of BRAFV600E_ driven tumorigenesis was unknown. Therefore, we hypothesized that pharmacologic group I PAK inhibition, alone or in combination with BRAFV600E or AKT inhibitors, depending on cell context, are effective treatment strategies.

In this study, we demonstrated that group I PAK activity in thyroid cancer can be inhibited by both G-5555 and FRAX1036 and that G-5555 was more (c) 2019 Society for Endocrinology Published by Bioscientifica Ltd. Printed in Great Britain 
potent. PAK inhibition reduced thyroid cancer cell viability, cell cycle progression, migration and invasion in vitro. Further, G-5555 and a BRAFV600E inhibitor were synergistic on thyroid cancer cell viability in BRAFV600E thyroid cell lines and with an AKT inhibitor in a PIK3CAmutated thyroid cancer cell line. Finally, oral treatment with G-5555 restrained BRAFV600E-driven thyroid size and reduced tumor formation in a mouse model of inducible thyroid-specific BRAFV600E overexpression. These data provide further evidence that group I PAKs are important for thyroid cancer growth and motility, that they may be exploited for therapeutic intent, and that PAK likely plays an important role in BRAFV600E-mediated thyroid tumorigenesis.

\section{Materials and methods}

\section{Cell lines and cell culture}

The following human thyroid cancer cell lines (Supplementary Table 1, see section on supplementary data given at the end of this article, Landa et al. 2019) were used: TPC1 (Tanaka et al. 1987), FTC133 (Goretzki et al. 1990), BCPAP (Fabien et al. 1994), SW1736 (Xu et al. 2003), 8505C (Ito et al. 1994), hTh74 (Heldin et al. 1991), K1 (Challeton et al. 1997) and THJ-16T (Marlow et al. 2010). Cells were cultured as described in the Supplementary Materials.

\section{In vitro drug reagents}

The following drugs were used: FRAX1036, group I PAK inhibitor (generous gift from Dr Jonathan Chernoff, Fox Chase Cancer Center, Philadelphia, PA, USA); G-5555, group I PAK inhibitor (HY-19635; MedChemExpress, Monmouth Junction, NJ, USA); PLX4032, BRAFV600E inhibitor (S1267; Selleckchem, Houston, TX, USA), MK2206, AKT inhibitor (HY-10358; MedChemExpress). For in vitro assays, drugs were reconstituted in DMSO.

\section{Cell viability assays}

Cell lines were optimized for seeding density in 96-well plates. Cells were treated with the indicated drug in 1\% FBS for $72 \mathrm{~h}$. WST-8 (Cell Counting Kit-8, Dojindo Molecular Technologies, Inc.) was added and the optical density (OD) was read at $450 \mathrm{~nm}$. The percent viability was calculated by comparing the OD of treated cells versus untreated cells. At least three biological replicates in triplicate were performed for each cell line.

\section{Protein extraction and Western blots}

Cells were seeded on $10 \mathrm{~cm}$ plates and treated with the indicated compounds in 1\% FBS for $24 \mathrm{~h}$ (G-5555, FRAX1036, and combination of G-5555+MK2206) or $3 \mathrm{~h}$ (combination of G-5555+PLX4032). Cells were scraped, pelleted and lysed in mammalian protein extraction reagent (MPER, Thermo Fisher Scientific). Protein concentration was estimated using the Pierce BCA Protein Assay Kit (Thermo Fisher Scientific). Proteins were separated by Western blot as described in the Supplementary Materials. At least two biological replicates were performed per cell line for each treatment.

\section{Cell cycle analysis}

TPC1, SW1736 and FTC133 cells were treated with $0.5 \mu \mathrm{M}$ G-5555, $5 \mu$ M FRAX1036 or DMSO-only control for 24 and $48 \mathrm{~h}$. Cells were collected and fixed with 70\% ethanol. For analysis of DNA content, the cells were resuspended in propidium iodide (PI) solution $(40 \mu \mathrm{g} / \mathrm{mL}$ PI, $100 \mu \mathrm{g} / \mathrm{mL}$ RNAse A in PBS). Cells were filtered and analyzed using the LSR II flow cytometer (BD Biosciences) by the Analytical Cytometry Core. Three biological replicates were performed for each cell line.

\section{Migration and invasion assays}

Migration and invasion of TPC1 and FTC133 cells were conducted as detailed in the Supplementary Materials and as previously reported by our lab (McCarty et al. 2010).

\section{Thyroid-specific inducible BRAFV600E mouse model}

We utilized a thyroid-specific inducible BRAFV600E mouse model previously described by Chakravarty et al. (2011) and generously gifted to us by Dr James Fagin (Memorial Sloan-Kettering Cancer Center, New York, NY, USA).

\section{G-5555 treatment in vivo}

For in vivo G-5555 treatment, dosing strategy was followed in accordance with Ndubaku et al. (2015). G-5555 hydrochloride (MedChemExpress, HY-19635A) was dissolved in MCT vehicle $(0.5 \%(\mathrm{w} / \mathrm{v})$ methylcellulose, $0.2 \%(\mathrm{w} / \mathrm{v})$ Tween 80 in sterile water) at $2.5 \mathrm{mg} / \mathrm{mL}$ and sonicated for $30 \mathrm{~min}$ at $4^{\circ} \mathrm{C}$. Male and female mice on the $\mathrm{FVB} / \mathrm{N}$ background were randomly divided into groups containing littermate controls. Three cohorts of mice, aged 10.5-22 weeks old and treated within months of 
each other, were tested with $4-8$ mice in each treatment group per cohort. Total number of mice is included in Fig. 7C. At the time mice were given doxycycline in the chow, they were administered either $25 \mathrm{mg} / \mathrm{kg}$ G-5555 or MCT vehicle with a dose volume of $10 \mathrm{~mL} / \mathrm{kg}$, via oral gavage, twice daily. After one week, mouse thyroids were harvested. One lobe was formalin-fixed for immunohistochemistry, one lobe was frozen. The thyroid volume of the frozen lobe was measured ex vivo. Volume $\left(\mathrm{mm}^{3}\right)$ was calculated using the following: $V=L \times W \times W \times 0.52$ (V=volume, $\mathrm{L}=$ diameter of long axis, $\mathrm{W}=$ diameter of short axis). All animal protocols, care and studies were approved by The Ohio State University Institutional Animal Care and Use Committee.

\section{Immunohistochemistry}

Conditions were optimized for each target and antibody by the Comparative Pathology \& Mouse Phenotyping Core. Details of analysis and antibodies are described in the Supplementary Materials.

\section{Protein extraction from mouse thyroids}

Thyroid lobes from individual mice were mechanically homogenized on ice in MPER buffer (Thermo Fisher Scientific). Lysates were centrifuged and the supernatants were concentrated using Amicon Ultra Centrifugal Filter devices with a $10 \mathrm{kDa}$ molecular weight limit (MilliporeSigma). Protein concentration was estimated using the Pierce BCA Protein Assay Kit (Thermo Fisher Scientific). 10-20 $\mu$ g of protein were separated on Western blots and analyzed, as detailed above. Quantitation of pPAK, pERK and GAPDH bands on the Western blot images was conducted using ImageJ software (version 1.51, NIH).

\section{Statistical analysis}

IC $_{50}$ values were estimated by four-parameter logistic regression models. For each drug and cell line combination, the weighted mean $\mathrm{IC}_{50}$ was calculated from individual experimental results using the inverse variance as the weight. Comparisons between G-5555 and FRAX1036 within a cell line were made by inverse variance weighted $t$-tests using the $\mathrm{IC}_{50}$ values from each experiment. In cell lines for which $\mathrm{IC}_{50}$ was not estimable, linear doseresponse slopes were compared between drugs using linear mixed models. Doses below $0.5 \mu \mathrm{M}$ were excluded due to lack of effect and to better fit the linear form of the models. The Holm's procedure was applied to each family of comparisons to control the familywise type I error rate at $\alpha=0.05$.

The following statistical analyses were conducted via GraphPad Prism 7. For cell cycle analysis, one-way ANOVA tests followed by Holm's procedure were conducted for each time point separately and separately within each phase in the cell cycle (i.e. G0/G1, S, G2/M) to compare the control, G-5555 and FRAX treatments. For migration, invasion and in vivo thyroid size, comparisons among different treatments were analyzed using one-way ANOVA followed by Holm's procedure. Analysis of carcinoma incidence was performed with a Fisher's exact test. Difference in Ki67 IHC staining was estimated with a Mann-Whitney $U$ test. Comparisons of in vivo protein expression and thyroid volume were fit with a linear regression line. For all tests, $P$ value $\leq 0.05$ was accepted as significant. ${ }^{* * *} P \leq 0.0001$, ${ }^{* * *} P \leq 0.001,{ }^{* *} P \leq 0.01,{ }^{*} P \leq 0.05$.

\section{Synergy statistics}

Combination drug experiments with G-5555 and PLX4032 or MK2206 were analyzed using the two-stage response surface models proposed by Zhao et al. (2012) building on the work of Harbron (2010) and the Loewe additivity model (Loewe 1953). The Zhao response surface models estimate a drug interaction index, $\tau$ (tau), for each non-zero dose combination. The interpretation of $\tau$ is as follows:

$$
\tau\left\{\begin{array}{cc}
<1 & \text { synergy, } \\
=1 & \text { additivity } \\
>1 & \text { antagonism }
\end{array}\right.
$$

Confidence intervals for the estimated $\tau$ indices were constructed using non-parametric bootstrapping techniques. Model parameterizations other than the Zhao model were considered: uniform, linear dependency, separate indices without the response surface relationship. AIC and BIC model fit criteria were compared between models and the Zhao model consistently had the best fit. Analyses were performed using the R package 'drugCombo' (Nazarov et al. 2018).

\section{Results}

\section{Group I PAK inhibition reduces thyroid cancer cell viability}

To determine the effects of group I PAK inhibition on thyroid cancer cell viability, a panel of validated human thyroid cancer cell lines with activated MAPK and/or AKT 
pathways (detailed in Methods section and Supplementary Table 1) were treated with increasing doses of G-5555 or FRAX1036 and cell viability was estimated after $72 \mathrm{~h}$ using a water-soluble tetrazolium (WST) reagent (Fig. 1). IC 50 doses were calculated (Table 1). In all cell lines tested, PAK inhibition reduced cell viability and, even in the relatively resistant FTC133 cell line, G-5555 was more potent than FRAX1036. The most sensitive cell line was TPC1, with an $\mathrm{IC}_{50}$ for G-5555 of $0.50 \mu \mathrm{M}$ and for FRAX1036 of $3.94 \mu \mathrm{M}$. Most cell lines tested, with the exception of TPC1, hTh74 and BCPAP, did not reach a calculable $\mathrm{IC}_{50}$ for FRAX1036, but had $\mathrm{IC}_{50}$ values below $7 \mu \mathrm{M}$ for G-5555. FTC133 has mutational loss of PTEN (Goretzki et al. 1990, Landa et al. 2019); to determine whether PI3K activation corresponded with PAK inhibitor resistance, we also treated the THJ16T cell line that has an activating PIK3CA mutation (Marlow et al. 2010). These cells were sensitive to G-5555 with an $\mathrm{IC}_{50}$ of $2.57 \mu \mathrm{M}$; thus, these data suggest that the resistance is likely cell line specific rather than due to activated AKT. In all cell lines, we confirmed that G-5555 and FRAX1036 reduced PAK signaling in a dose-dependent manner (Fig. 2). PAK1 and PAK2 autophosphorylation at serine 144 and serine 141, respectively, showed a dose-dependent reduction, and downstream specific phosphorylation sites of PAK, vimentin at serine 55 and MEK1 at serine 298, showed a parallel decrease. There was no inhibition of phosphorylated AKT, consistent with the kinase-independent role of PAK as a scaffold in AKT signaling (Higuchi et al. 2008). These data indicate that G-5555 and FRAX1036 inhibit PAK activity, that G-5555 is more potent than FRAX1036, and that in all but one tested thyroid cancer cell lines, the compounds are active in vitro.

\section{G-5555 in combination with BRAFV600E or AKT inhibitors synergistically reduces K1 and SW1736 cancer cell viability}

We next tested the effects of combining G-5555 with a BRAFV600E inhibitor, Vemurafenib (PLX4032) or an allosteric AKT inhibitor, MK2206 (Liu et al. 2011). Cell lines were tested for sensitivity to individual treatment with PLX4032 (Fig. 3A and Supplementary Table 2) or MK2206 (Fig. 4A and Supplementary Table 2) and showed varied responses in viability. In general, the cell lines with BRAFV600E mutation tended to be more sensitive to PLX4032 treatment, as previously reported (Xing et al. 2011), while in our conditions, genotype was modestly predictive of MK2206 sensitivity, as the two lines with isolated PI3K activating genetic changes (FTC133 and THJ-16T) had $\mathrm{IC}_{50}<5 \mu \mathrm{M}$, consistent with prior reports (Liu et al. 2009).

SW1736, TPC1 and FTC133 cells were chosen for subsequent combination treatment, as they are
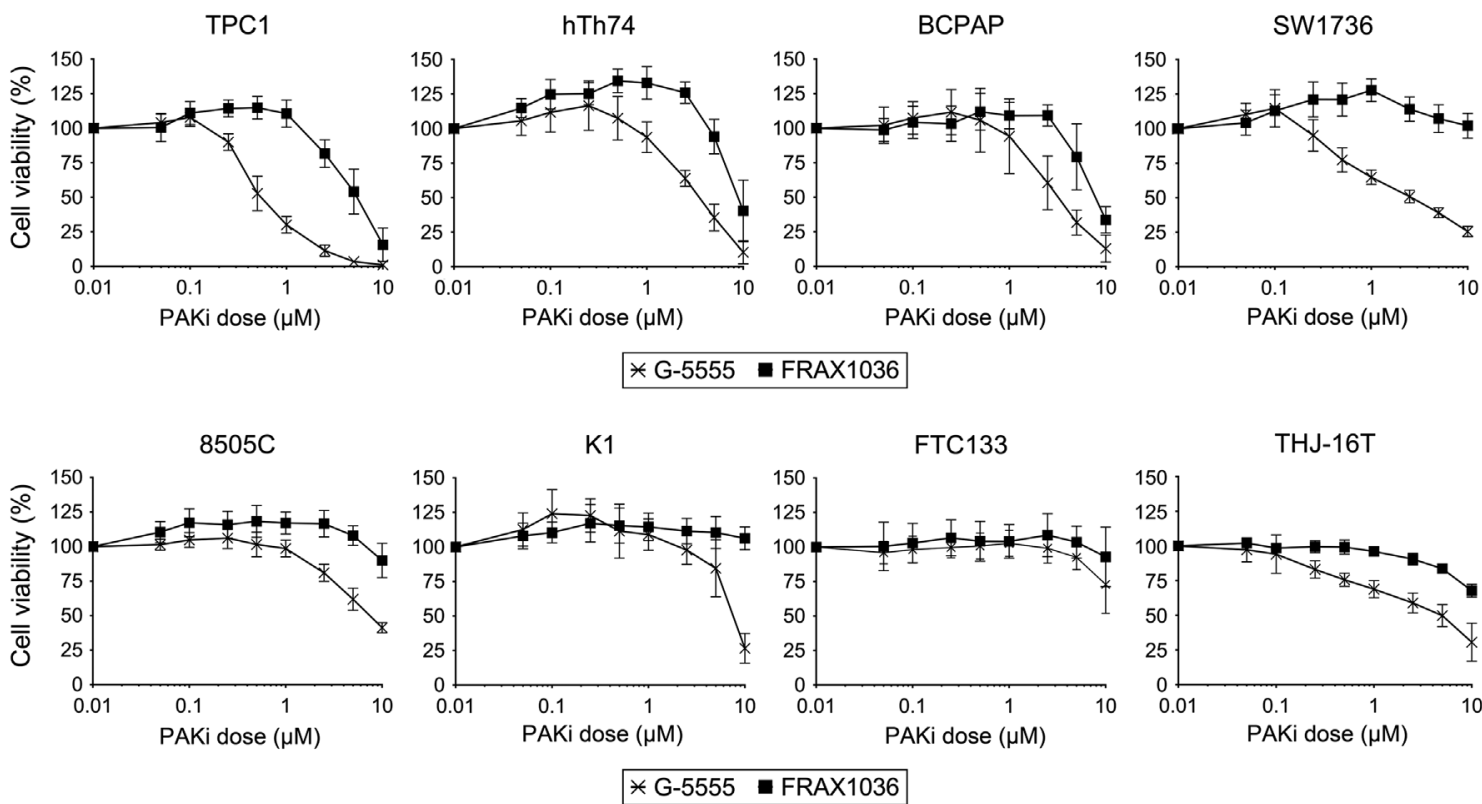

Figure 1

Effects of group I PAK inhibition on cell viability. A panel of eight thyroid cancer cell lines was treated with increasing doses of G-5555 or FRAX1036 for $72 \mathrm{~h}$. Cell viability was determined by colorimetric WST-8 assay. The optical density of each treatment was normalized to the $0 \mu \mathrm{M}$ control. Assays were conducted in triplicate with at least three biological replicates. Data are represented as means \pm s.D. 
Table 1 Estimated IC 50 concentrations $(\mu \mathrm{M})$ for G-5555 and FRAX1036.

\begin{tabular}{|c|c|c|c|c|c|c|}
\hline Cell line & G-5555 $(\mu \mathrm{M})$ & S.E. & $95 \% \mathrm{Cl}$ & FRAX1036 $(\mu \mathrm{M})$ & S.E. & $95 \% \mathrm{Cl}$ \\
\hline \multicolumn{7}{|c|}{ Estimated $I_{50}$ concentrations $(\mu \mathrm{M})$ for $\mathrm{G}-5555$ and FRAX1036 in human thyroid cancer cell lines } \\
\hline TPC1 & $0.50^{\mathrm{a}}$ & 0.04 & $(0.41-0.59)$ & 3.94 & 0.36 & $(3.08-4.80)$ \\
\hline BCPAP & $2.46^{a}$ & 0.49 & $(1.31-3.60)$ & 7.73 & 0.31 & (6.96-8.49) \\
\hline HTh74 & $3.36^{a}$ & 0.25 & $(2.72-4.01)$ & 6.14 & 0.35 & (5.17-7.10) \\
\hline SW1736 & $1.37 a$ & 0.10 & $(1.12-1.62)$ & $>10$ & & \\
\hline $8505 C$ & $6.64^{a}$ & 0.54 & $(5.40-7.88)$ & $>10$ & & \\
\hline $\mathrm{K} 1$ & $6.98^{a}$ & 0.65 & (5.32-8.65) & $>10$ & & \\
\hline FTC133 & $>10^{b}$ & & & $>10$ & & \\
\hline THJ-16T & $2.60^{a}$ & 0.40 & $(1.83-3.38)$ & $>10$ & & \\
\hline
\end{tabular}

The $\mathrm{IC}_{50}$ for each cell line and each drug were estimated using the viability data represented in Fig. 1. Significant differences between G-5555 and FRAX1036 were calculated by inverse variance weighted $t$-tests when the $\mathrm{I}_{50}$ was calculable and by linear mixed models of dose-response slopes if the $I_{50}$ was $>10 \mu \mathrm{M}$.

$\mathrm{a} P \leq 0.001, \mathrm{~b} P \leq 0.01$.

representative of the most common genotypic alterations in thyroid cancer. K1 also was evaluated, as it has activating mutations in BRAF and PIK3CA and was relatively resistant to both PLX4032 and MK2206 monotherapies. In two cell lines with BRAFV600E, K1 and SW1736, combination of PLX4032 and G-5555 synergistically decreased cell viability (Fig. 3B). In K1 cells, synergy was detected between 1 and $5 \mu \mathrm{M}$ G-5555 with 0.5-5 $\mathrm{MM}$ PLX4032, indicated by the shaded combinations, with the darker shading being more synergistic (Fig. 3C). In SW1736 cells, synergy was detected mainly between 0.25 and $1 \mu \mathrm{M}$ G-5555 with 0.1 and $5 \mu \mathrm{M}$ PLX4032. Decrease in PAK and MAPK activity was analyzed by Western blot (Fig. 3D). Cells without BRAFV600E had mainly antagonistic effects with the PLX4032 and G-5555 combination, both in cell viability and signaling (Supplementary Fig. 1), as predicted by the known increase in MAPK signaling that occurs with treatment of WT BRAF cells with PLX4032 (Poulikakos et al. 2010, Montero-Conde et al. 2013).

$\mathrm{K} 1$ cells also had a synergistic decrease in cell viability with combination of G-5555 and the AKT inhibitor, MK2206, as predicted by the PIK3CA-activating mutation (Fig. 4B and C). In SW1736 cells, there were only mild synergistic effects at higher doses of MK2206, consistent with the absence of activation of PI3K signaling in this cell line (Fig. 4B and C). In both cell lines, decreased pPAK S144/141 with addition of G-5555 and pAKT S473 and $\mathrm{pGSK}-3 \alpha / \beta$ S21/9 with MK2206 were identified,
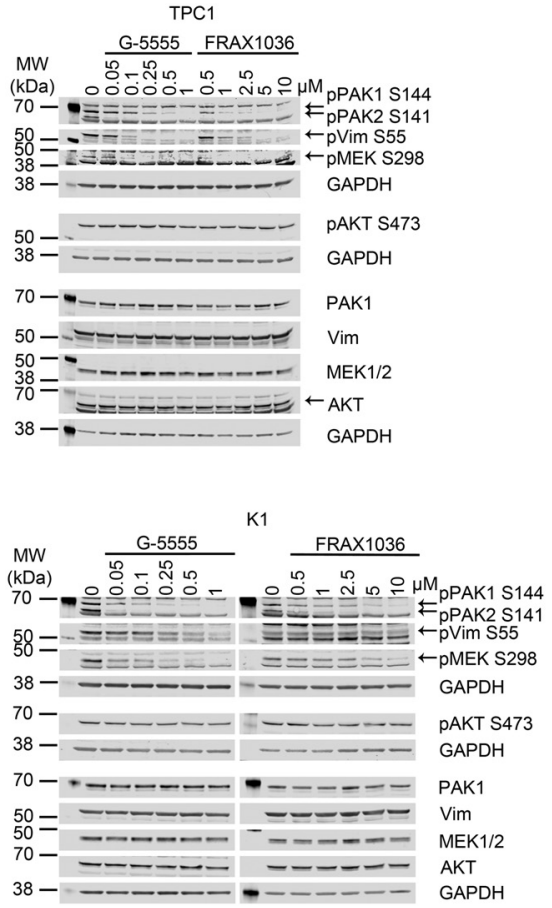
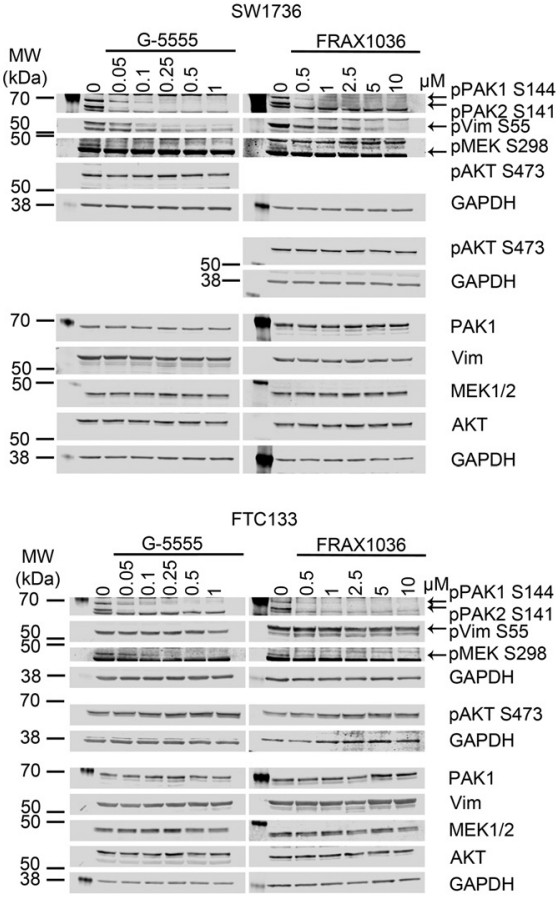

Figure 2

PAK signaling with group I PAK inhibition. TPC1, SW1736, K1 and FTC133 cells were treated with increasing doses of G-5555 or FRAX1036 for $24 \mathrm{~h}$ to avoid significant toxicity. Western blots of downstream PAK targets were conducted to confirm drug activity. GAPDH was used as a loading control and is shown below blots on the same membrane. For SW1736 G-5555, pAKT S473 was blotted on the same membrane as the first GAPDH and is grouped accordingly. At least two biological replicates were performed per cell line and results were similar. https://erc.bioscientifica.com

https://doi.org/10.1530/ERC-19-0188 (c) 2019 Society for Endocrinology Published by Bioscientifica Ltd. Printed in Great Britain 
confirming activity of the compounds (Fig. 4D). pPAK S144/141 also moderately decreased with MK2206 alone, but the exact mechanism remains to be elucidated. In TPC1 and FTC133, combination of G-5555 and MK2206 had minimal or no synergy, with some mild antagonistic combinations (Supplementary Fig. 2). Taken together, these results indicate combination of G-5555 with a BRAFV600E or AKT inhibitor can have synergistic effects on decreasing cell viability in thyroid cancer cells that appear to be predicted, in part, by driver oncogenes.

\section{Reduction in cell viability by group I PAK inhibition corresponds with cell cycle arrest in G0/G1}

PAKs activate key regulators of cell cycle progression ( $\mathrm{Li}$ et al. 2002, Zhao et al. 2005, Maroto et al. 2008). Thus, we analyzed the effects of group I PAK inhibition on cell cycle using PI and flow cytometry. Based on initial time course and dose-response experiments confirming inhibition of PAK activity and viability differences, TPC1, SW1736 and FTC133 were treated with $0.5 \mu \mathrm{M}$ G-5555 or $5 \mu \mathrm{M}$ FRAX1036 for 24 (Fig. 5A) or $48 \mathrm{~h}$ (Fig. 5B). In TPC1, the cell line that was most sensitive to growth inhibition by
G-5555 and FRAX1036 (Fig. 1), both compounds induced arrest in G0/G1 phase at $24 \mathrm{~h}$, with concordant reductions of cells in S and G2/M (Fig. 5A). These effects remained after $48 \mathrm{~h}$, although with more variability (Fig. 5B). Similarly, and consistent with cell viability effects (Fig. 1), the accumulation of SW1736 in G0/G1 after 24 and 48 h was greater for G-5555 than FRAX1036 (Fig. 5). Conversely, in FTC133, the cell line that was mostly resistant to growth inhibition by both G-5555 and FRAX1036 (Fig. 1), neither compound altered cell cycle progression at either 24 or $48 \mathrm{~h}$ (Fig. 5). These data demonstrate that the reduction in cell viability with group I PAK inhibition is associated with G0/G1 arrest.

\section{G-5555 reduces thyroid cancer cell migration and invasion}

In addition to cell proliferation, group I PAKs are important for the rearrangement of the cytoskeleton and are key regulators of cell migration (Goto et al. 2002, Tang et al. 2005, Nayal et al. 2006, Radu et al. 2014). We previously reported increased PAK activity at the invasive fronts of aggressive PTCs and that molecular inhibition
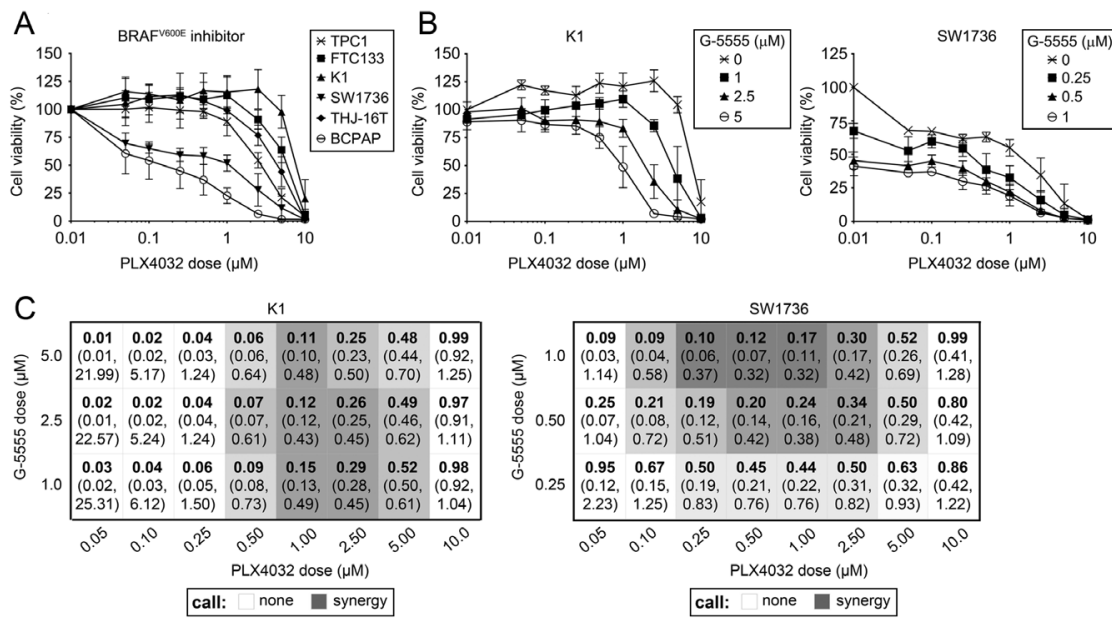

D K1

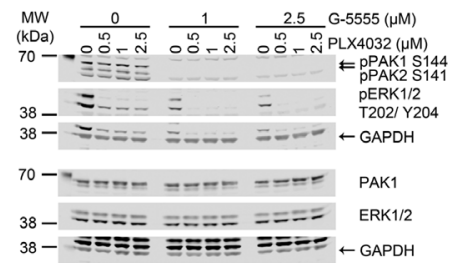

38 - シミミミミシミミミシニこ $\leftarrow \mathrm{GAPDH}$
Figure 3

Combination treatment with BRAFV600E and PAK inhibitors in BRAFV600 cell lines. (A) Six thyroid cancer cell lines were treated with increasing doses of BRAFV600E inhibitor (PLX4032) alone for $72 \mathrm{~h}$. Cell viability was determined by colorimetric WST-8 assay. The optical density of each treatment was normalized to the $0 \mu \mathrm{M}$ control. Assays were conducted in triplicate with at least three biological replicates. Data are represented as means \pm S.D. (B) WST-8 cell viability assay of K1 and SW1736 after $72 \mathrm{~h}$ of combined BRAFV600E (PLX4032) and PAK (G-5555) inhibition at the specified combination of doses. All dose combinations were normalized to the $0 \mu \mathrm{M}$

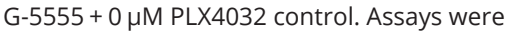
conducted in triplicate with at least three biological replicates. Data are represented as means \pm S.D. (C) Synergy tables representing each PLX4032/G-5555 combination using the model from Zhao et al. (2012). The bolded top numbers are the drug interaction indices, $\tau$ and the bottom numbers in parentheses are the confidence intervals. Synergy is defined as $\tau<1$ and upper confidence limit $<1$. The darker shading indicates stronger synergy. (D) Western blot of PAK signaling (pPAK S144/S141) and BRAF signaling (pERK T202/Y204) at doses and timing selected for synergy and cell viability. GAPDH is used as the loading control for the membrane above it. At least two biological replicates were performed per cell line and results were similar. (c) 2019 Society for Endocrinology Published by Bioscientifica Ltd. Printed in Great Britain 
of PAK1 reduced thyroid cancer migration (McCarty et al. 2010). In addition, PAK inhibition by G-5555 reduced phosphorylated vimentin (Fig. 2), suggesting that PAK regulation of intermediate filaments might be reduced by the compound. Therefore, we tested the ability of G-5555 to reduce TPC1 and FTC133 migration and invasion in transwell assays without (migration) or with (invasion) Matrigel coating. Cells were seeded on top of a Boyden chamber and treated with G-5555 for $16 \mathrm{~h}$. The chambers were stained with crystal violet and the extracted color from the stained cells was compared between the top (non-migrated) and bottom (migrated) layers, and images of the invading cells were quantified. In both TPC1 and FTC133, G-5555 reduced migration (Fig. 6A). In TPC1, $0.25 \mu \mathrm{M}$ significantly reduced migration to $\sim 50 \%$ and $1 \mu \mathrm{M}$ G-5555 had even further reduction to $24 \%$ migration. An $~ 47 \%$ decrease in migration for FTC133 occurred with $1 \mu \mathrm{M}$ G-5555. Additionally, G-5555 was effective in reducing both TPC1 and FTC133 invasion (Fig. 6B and C), with similar trends in sensitivity as in the migration assays. Cell viability was tested in parallel to confirm no difference in viability in the conditions of the migration and invasion experiments (Fig. 6D). Together, these data indicate that G-5555 reduces thyroid cancer cell motility and invasiveness at sub-lethal doses, even in cells that are resistant to its cytotoxic effects at higher doses.

\section{BRAFV600E-increased thyroid size and cancer development in vivo is inhibited by G-5555}

The in vivo effects of G-5555 have been reported only in xenograft models of colon, non-small cell lung and breast cancers (Ndubaku et al. 2015, Rudolph et al. 2016, Chow et al. 2018). In these studies, G-5555 was effective at reducing xenograft tumor growth. To our knowledge, it has not been studied in a transgenic, immune-competent cancer model. In addition, the impact of PAK signaling on BRAF ${ }^{600 E}$ effects has not been studied directly in vivo in transgenic model systems. Therefore, we sought to determine the effects of G-5555 in an immune-competent thyroid cancer model in vivo. For these experiments, we utilized the robust and highly reproducible thyroidspecific inducible BRAFV600E overexpression mouse model of thyroid cancer (Chakravarty et al. 2011), in which acute induction of BRAFV600E in the mouse thyroid leads to human-like PTC in 1 week in nearly all mice. Using this model, we previously reported concurrent PAK upregulation and activation (McCarty et al. 2014). G-5555 or vehicle control was given orally twice a day for a week beginning on the same day as

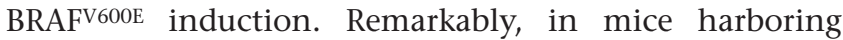
BRAFV600E thyroids, treatment with G-5555 resulted in smaller thyroids by $52.1 \%$ compared to vehicle controls
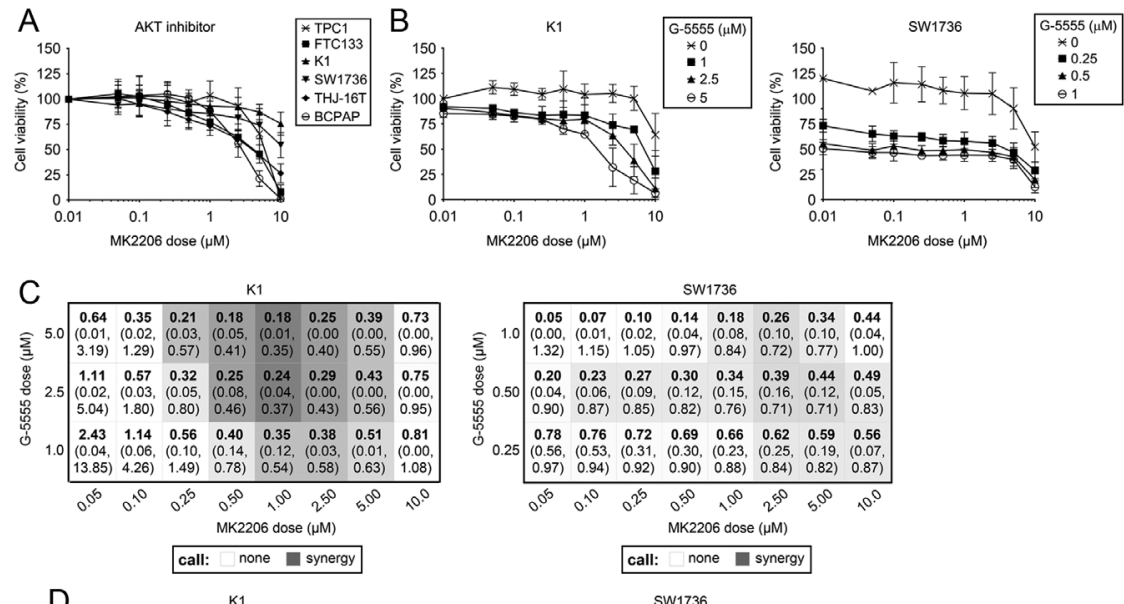

D
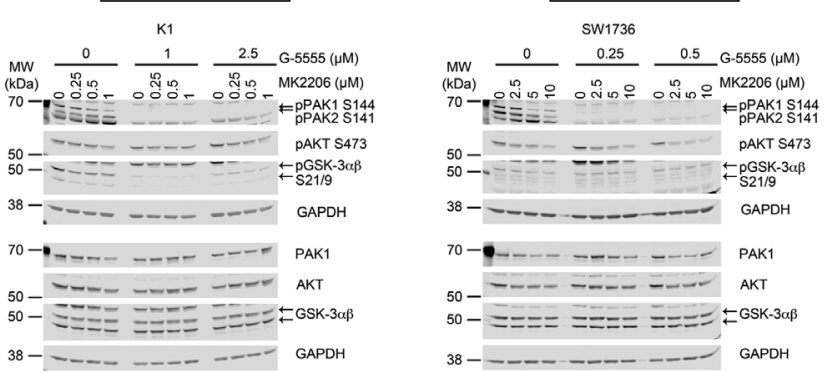

\section{Figure 4}

Combination treatment with AKT and PAK inhibitors in BRAFV600E cell lines. (A) Thyroid cancer cell lines were treated with increasing doses of AKT inhibitor (MK2206) alone for $72 \mathrm{~h}$. Cell viability was determined by WST-8 assay. The optical density of each treatment was normalized to the $0 \mu \mathrm{M}$ control. Assays were conducted in triplicate with at least three biological replicates. Data are represented as means \pm S.D. (B) WST-8 cell viability assay of K1 and SW1736 after $72 \mathrm{~h}$ of combined AKT (MK2206) and PAK (G-5555) inhibition. All dose combinations were normalized to the $0 \mu \mathrm{M}$ G-5555 + 0 нM MK2206 control. Experiments were conducted in triplicate with $\geq$ three biological replicates. Data are represented as means \pm S.D. (C) Synergy tables representing MK2206/G-5555 combinations as per Zhao et al. (2012) and as described in Fig. 3. (D) pPAK S144/S141, pAKT S473 and pGSK-3 $\alpha \beta$ S21/9 are shown at doses and timing selected for synergy and cell viability. GAPDH is loading control for each membrane above it. At least two biological replicates were performed per cell line with similar results. (c) 2019 Society for Endocrinology Published by Bioscientifica Ltd. Printed in Great Britain 
(mean volume 1.902 vs $\left.3.97 \mathrm{~mm}^{3}, P<0.0001\right)$ (Fig. 7A). G-5555 did not have an effect on the size of noninduced thyroids compared to vehicle controls (0.591 vs $\left.0.429 \mathrm{~mm}^{3}, \quad P=0.8362\right)$. Histopathological analysis confirmed that in mice without BRAFV600E induction, all thyroids exhibited normal histology (Fig. 7B and C). In mice with BRAFV600E induction, 15 mice treated with vehicle developed thyroid carcinomas and only one mouse had thyroid hyperplasia. Surprisingly, for those mice with BRAFV600E and treated with G-5555, six had hyperplasia, two formed follicular adenoma and only nine developed carcinoma. In comparing the incidence of benign pathology and carcinoma in the mice with BRAFV600E, G-5555 significantly reduced carcinoma formation $(P=0.0167)$. Ki67 analysis in these mice indicated a mild trend toward a decrease in thyroid cell proliferation with G-5555 treatment $(P=0.1078)$, consistent with the higher incidence of benign thyroid glands (Supplementary Fig. 3A). All thyroids, regardless of treatment, had less than $1 \%$ of cells with positive cytosolic staining for cleaved caspase-3 (Supplementary Fig. 3B), and therefore, the difference in thyroid size in mice with BRAFV600E and G-5555 treatment is likely not due to an increase in apoptosis, consistent with the in vitro observation that G-5555 inhibits cell cycle progression (Fig. 5).

Induction of BRAFV60E in the thyrocytes resulted in activation of ERK1/2, localized nearly exclusively to the thyrocytes (Fig. 7D), consistent with reported observations (Chakravarty et al. 2011). The available pPAK antibodies proved to be unreliable for immunohistochemical analysis. Protein from individual mouse thyroids were isolated and analyzed by Western blot and compared to the thyroid volume. pERK levels did not correspond with thyroid size (Fig. 7E and Supplementary Fig. 4); however, pPAK144/141 levels positively associated with thyroid size (Fig. 7E and F). Taken together, these data show that G-5555 restrains BRAFV60E-driven thyroid size and carcinoma formation, even with continued activation of MAPK signaling and suggest that active PAK contributes to tumorigenesis in this mouse model of thyroid cancer.

\section{Discussion}

Alternative treatment strategies for aggressive thyroid cancers are needed to improve clinical outcomes. Our previous studies demonstrated an important functional role for activated PAK1 in aggressive PTC and that PAK activation is functionally regulated by BRAFV600E in a MEK-independent manner using molecular inhibitors (Vasko et al. 2007, McCarty et al. 2010, 2014). In the present study, we extend these findings and report that pharmacologic inhibition of group I PAKs may be useful as both a monotherapy (Fig. 1) and in combination with BRAFV600E (Fig. 3) and AKT (Fig. 4) inhibition. IC $_{50}$ concentrations and the concentrations required to inhibit PAK were lower for G-5555 than FRAX1036 (Fig. 2 and Table 1), consistent with the known improved target selectivity and potency of G-5555 compared to FRAX1036 (Ndubaku et al. 2015). Cell genotype for MAPK and PI3K activation did not predict the degree of sensitivity to G-5555 or FRAX1036 monotherapy; however, in all cell
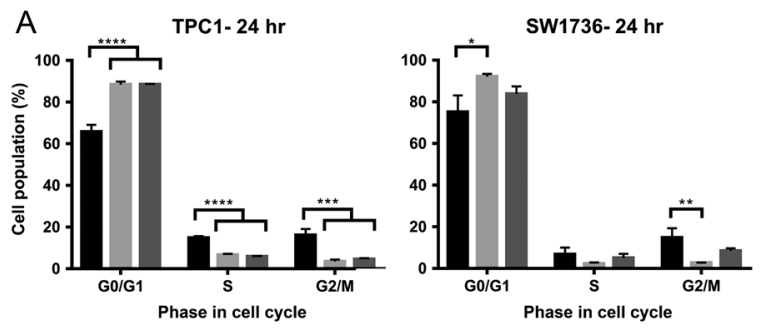

Control G-5555 GRAX1036
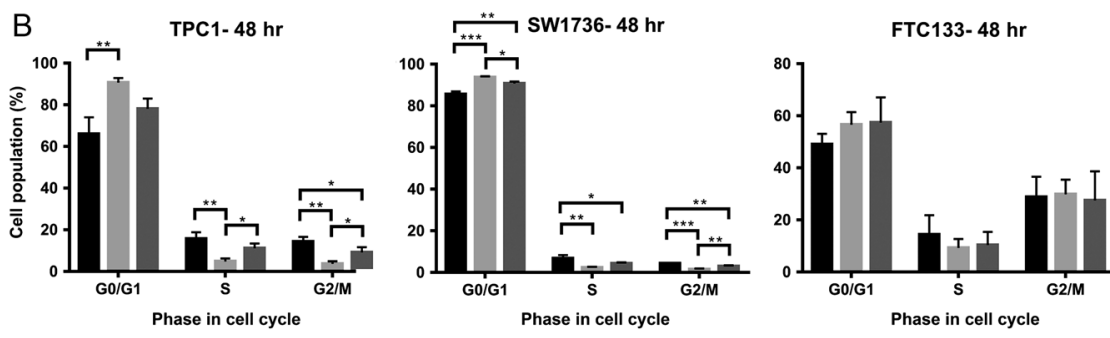

FTC133- $24 \mathrm{hr}$

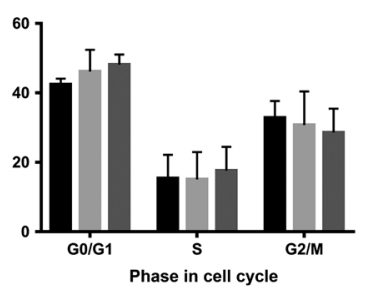

Figure 5

Cell cycle effects with group I PAK inhibition. TPC1, SW1736 and FTC133 were treated with DMSO, $0.5 \mu \mathrm{M}$ G-5555 or $5 \mu \mathrm{M}$ FRAX1036 for (A) 24 or (B) $48 \mathrm{~h}$. Cells were stained with PI and analyzed by flow cytometry for relative DNA amount. Statistical comparisons were made within each phase of the cell cycle by one-way ANOVA followed by Holm's procedure. Three biological replicates for each cell line and time point were performed and data are represented as means \pm S.D. ${ }^{* * * * P} \leq 0.0001,{ }^{* * * P} \leq 0.001$, $* * P \leq 0.01, * P \leq 0.05$. 

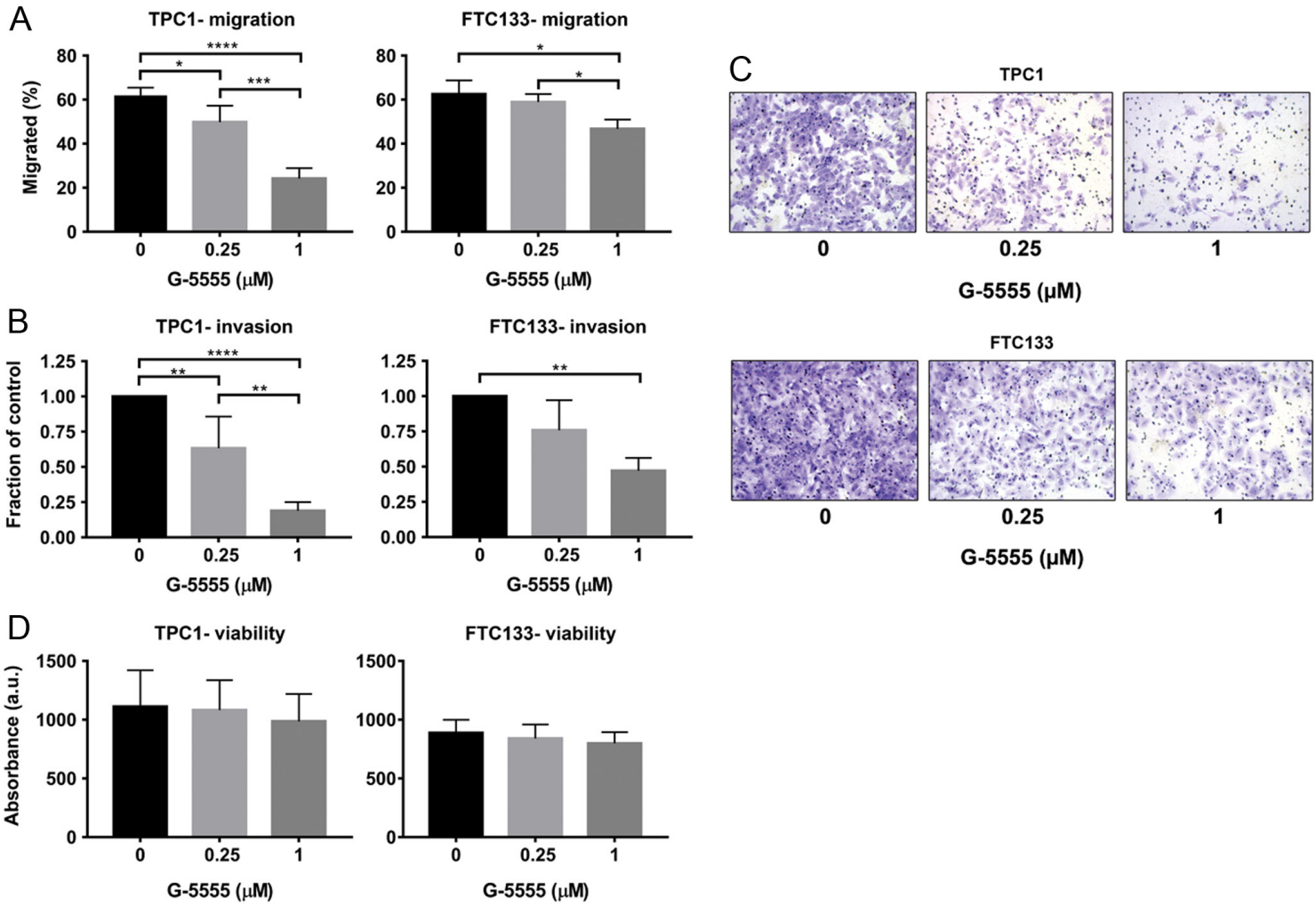

FTC133- viability

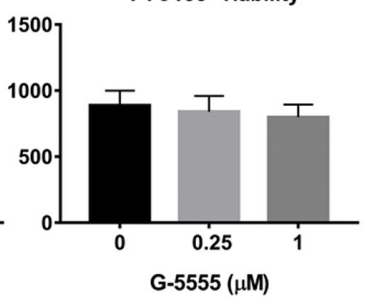

\section{Figure 6}

Effects of G-5555 on cell migration and invasion. TPC1 and FTC133 were seeded on top of Boyden chamber inserts without (A) or with (B) Matrigel coating. Cells were treated for $16 \mathrm{~h}$ with $0,0.25$ or $1 \mu \mathrm{M} \mathrm{G}-5555$. The top and bottom of the inserts were stained with crystal violet. For migration (A), percent migrated was calculated by comparing the OD of extracted crystal violet from the top and the bottom of the insert. For effects on invasion (B), the fraction of the control (i.e. $0 \mu \mathrm{M}$ G-5555) was calculated after counting the number of purple pixels from images of the bottom layer. (C) Representative images of invading cells are shown. (D) WST-8 viability assays were conducted in parallel and indicate no cytotoxic effects in these conditions. Cells were seeded in duplicate and at least three biological replicates for each cell line were performed. Data are represented as means \pm S.D. $* * * P \leq 0.0001, * * * P \leq 0.001, * * P \leq 0.01, * P \leq 0.05$.

lines tested, both G-5555 and FRAX1036 reduced PAK signaling (Fig. 2).

Because we have demonstrated that BRAFV000 regulates PAK, PAK is activated by several known mechanisms of BRAF inhibitor resistance (e.g. RAC1 mutations; Watson et al. 2014), and AKT and PAK functionally interact, we reasoned that PAK inhibition might enhance the efficacy of compounds targeting those pathways. Indeed, two BRAFV600E cell lines exhibited synergistic decreases in cell viability in response to G-5555 and PLX4032 combination therapy (Fig. 3), and K1, which also harbors a PIK3CA mutation, demonstrated synergy with MK2206 (Fig. 4). By contrast, synergy was not seen for G-5555 and PLX4032 in cells that had WT BRAF (Supplementary Fig. 1). These findings suggest that PAK inhibitors may be a potential combinatorial strategy for BRAF-mutated PTC. In addition to BRAF-mediated PAK activity (McCarty et al. 2014), PAK can be activated downstream of receptor tyrosine kinases, including HER3 or c-MET, that are involved in BRAF ${ }^{\mathrm{V} 600 \mathrm{E}}$ resistance. For example, group I PAKs are an important node in the regulation of c-MET signaling by inactivating merlin via phosphorylation at S518 (Kissil et al. 2002, Xiao et al. 2002). In some breast cancers, PAK1 is amplified and upregulates MAPK and MET signaling (Shrestha et al. 2012). In vitro and in a murine model of BRAFV600E-induced PTC, resistance to BRAFV600E inhibition was reported to be c-MET dependent (Byeon et al. 2016, 2017, Knauf et al. 2018). Thus, it is possible that combination therapy with a group I PAK inhibitor, such as G-5555, could block PAK phosphorylation of merlin, and subsequently allow merlin to negatively regulate c-MET. Further studies to determine the effects of G-5555 and PLX4032 combination in vivo are needed to determine if this might be a clinically important approach.

Cells that were sensitive to FRAX1036 or G-5555 monotherapy demonstrated G0/G1 arrest (Fig. 5). These results are consistent with observed cell cycle
C) 2019 Society for Endocrinology Published by Bioscientifica Ltd. Printed in Great Britain 
A

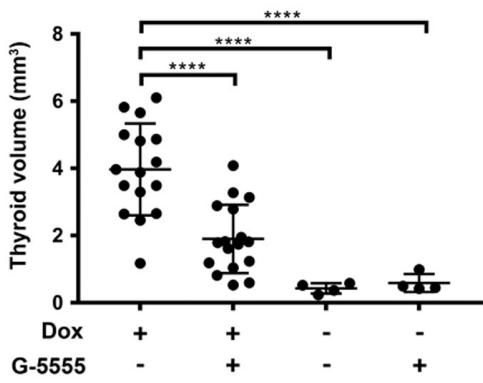

B

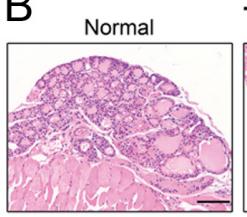

Benign

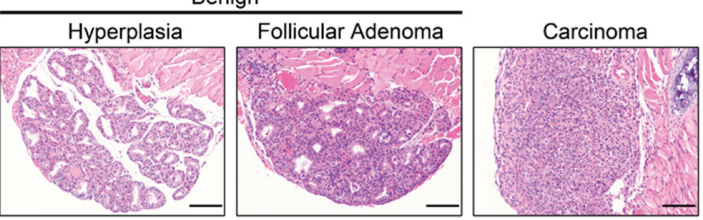

C

\begin{tabular}{|c|c|c|c|c|}
\hline Treatment & Normal & Benign & Carcinoma & Total \\
\hline No Dox/Vehicle & 4 & 0 & 0 & 4 \\
\hline No Dox/G-5555 & 4 & 0 & 0 & 4 \\
\hline Dox/Vehicle & 0 & 1 & 15 & 16 \\
\hline Dox/G-5555* & 0 & 8 & 9 & 17 \\
\hline
\end{tabular}

D

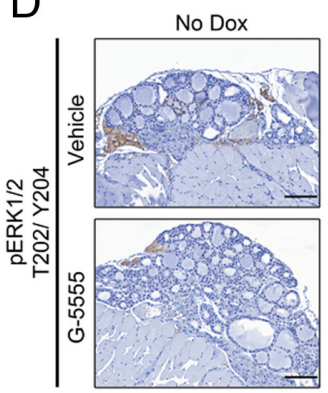

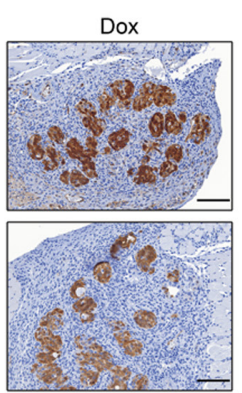

E MW

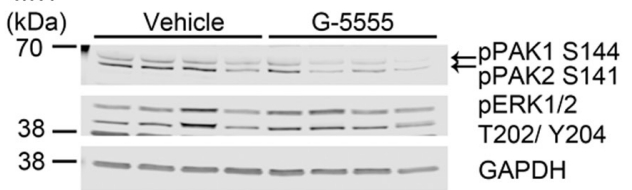

70-:ーーーーーー- PAK1

$38-$ ニニニニニニニ $=$ ERK $1 / 2$

38-- - - - - GAPDH
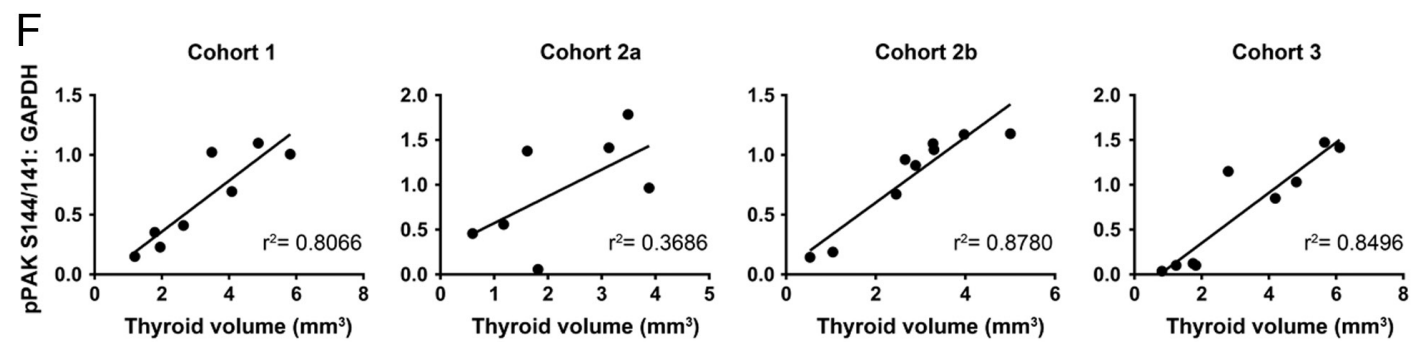

\section{Figure 7}

In vivo effects of G-5555 in a BRAFV60E-inducible thyroid cancer mouse model. BRAFV600E was induced in mouse thyroids by doxycycline-enriched chow for 1 week at the same time as G-5555 or vehicle oral gavage. Thyroids were harvested and volume (A) of one lobe was measured ex vivo. Comparisons among treatments were made by one-way ANOVA followed by Holm's procedure. Data are represented as individual plots with means \pm S.D.

$* * * * \leq 0.0001$. (B) Representative H\&E images of the thyroid pathologies observed. Scale bar $=100 \mu \mathrm{m}$. (C) Number of mice in each treatment group with the observed pathologies. Carcinoma incidence between Dox/Vehicle and Dox/G-5555 were compared using a Fisher's exact test. *P $\leq 0.05$. (D) Representative pERK1/2 T202/Y204 IHC images showing induction of BRAFV600E in the thyrocytes with Dox. Scale bar $=100 \mu \mathrm{m}$. (E) Western blot of Cohort 1 mouse thyroid lysates. Each lane is lysate from an individual mouse treated with Dox and vehicle or G-5555, as indicated. GAPDH is used as the loading control for the membrane above it. (F) Comparison of thyroid volume and quantification of the pPAK1/2 S144/141 Western blot bands normalized to GAPDH for each Western blot membrane. Each cohort of mice was treated at different times and the lysates from mice in Cohort 2 were divided on two gels ( $a$ and $b$ ), as titled. Comparisons were fit with a linear regression and the $r^{2}$ values are shown.

changes with group I PAK inhibition in meningioma cells (Chow et al. 2015). However, even in cells that survived PAK inhibition (FTC133, Fig. 1), G-5555 still reduced cell migration and invasion (Fig. 6), suggesting multiple roles for PAK in thyroid cancer. Consistent with this observation are reductions in phosphorylated vimentin (Fig. 2) and our previous work that showed PAK-dependent cell migration using molecular inhibitors (McCarty et al. 2010). Therefore, treatment with G-5555 could be a viable strategy to block the local invasion of thyroid cancers (McCarty et al. 2010).

Importantly, we tested the effect of PAK inhibition in a transgenic model of BRAFV600E-mediated PTC.
This model was chosen due to its robust MAPK signaling effects, the highly predictable development of PTC, and because we previously reported increased PAK expression and activity in this model (McCarty et al. 2014). We opted for a short-term model to avoid potential cardiac toxicity that might occur with long-term PAK inhibition (Rudolph et al. 2016). It is striking that even with such strong activation of MAPK, inhibition of PAK significantly restrained thyroid size and also reduced tumorigenesis. This is consistent with recent work in a colon cancer mouse model where inhibition of group I PAK activity by the PAK inhibitory domain (PID) reduced adenocarcinoma (c) 2019 Society for Endocrinology Published by Bioscientifica Ltd. Printed in Great Britain 
formation (Chow et al. 2018). Additionally, levels of pPAK positively corresponded with thyroid size, while levels of pERK did not (Fig. 7F and Supplementary Fig. 4). These data support the prior observations from our group and others (Babagana et al. 2017) of a MEK-independent role of BRAF-mediated PAK activation in cell cycle progression, proliferation and motility, suggesting that both PAK and ERK activation are required for maximal BRAFV600E effect in the thyroid. The latter hypothesis requires further thyrocyte-specific approaches for confirmation.

There are several caveats to our in vivo approach. G-5555 is a systemic therapy; therefore, this model does not differentiate between thyrocyte and non-thyrocyte involvement of PAK. Although G-5555 is a specific and potent PAK inhibitor and we demonstrated on-target effects, off-target effects can still occur. Additionally, we have not yet studied a treatment model, as we treated mice with G-5555 and doxycycline simultaneously; however, studies with delayed treatment are challenging using this model in which the inducible BRAFV600E allele is 'turned off' due to thyroid dedifferentiation. Despite these important caveats, we believe the striking effects of the PAK inhibitor on a potent model of BRAFV600E-induced tumor formation, in the context of continued activation of MAPK signaling, are novel and consistent with our prior data. Together, these data strongly implicate a critical role for PAK in BRAFV600E-induced thyroid tumorigenesis.

In summary, we have shown that group I PAKs are critical signaling molecules in thyroid growth, tumorigenesis and progression, and may be therapeutically targetable in several genetic contexts. Further investigation into the safety and dosing strategy of G-5555 alone and in combination with BRAFV600 ${ }^{\mathrm{V}}$ or AKT inhibition is needed using additional mouse models of thyroid cancer, as this may lead to alternative treatment options for patients with progressive thyroid cancer.

\section{Supplementary data}

This is linked to the online version of the paper at https://doi.org/10.1530/ ERC-19-0188.

\section{Declaration of interest}

The authors declare that there is no conflict of interest that could be perceived as prejudicing the impartiality of the research reported.

\section{Funding}

This work was supported by an NCl grant (1R01CA227847-01) to M D R, $\mathrm{NIH}$ cancer center grant (P30CA016058) to The Ohio State University and Pelotonia Fellowship Program award to C M K.

C) 2019 Society for Endocrinology Published by Bioscientifica Ltd. Printed in Great Britain

\section{Author contribution statement}

Conceptualization: M D R, C M K and M S. Methodology: C M K, M D R and M S. Resources: M S, K P and K M D L P. Investigation: C M K, N R and M S. Software: K P. Formal analysis: C M K, M D R, M S, KP and KM D LP. Visualization: $C M K, N R$ and $K$ P. Writing-original draft: $C M K$ and $M D R$. Writing-review and editing: All authors. Funding acquisition: $M D R$ and C M K. Supervision: M D R and M S.

\section{Acknowledgements}

The authors thank Jonathan Chernoff, MD, PhD (Fox Chase Cancer Center, Pennsylvania) for generously sharing reagents. They also thank the OSU Analytical Cytometry, Biostatistical, and the Comparative Pathology \& Mouse Phenotyping shared resources for their valuable technical expertise.

\section{References}

Babagana M, Johnson S, Slabodkin H, Bshara W, Morrison C \& Kandel ES 2017 P21-activated kinase 1 regulates resistance to BRAF inhibition in human cancer cells. Molecular Carcinogenesis 56 1515-1525. (https://doi.org/10.1002/mc.22611)

Brose MS, Cabanillas ME, Cohen EE, Wirth LJ, Riehl T, Yue H, Sherman SI \& Sherman EJ 2016 Vemurafenib in patients with BRAF(V600E)-positive metastatic or unresectable papillary thyroid cancer refractory to radioactive iodine: a non-randomised, multicentre, open-label, phase 2 trial. Lancet Oncology 17 1272-1282. (https://doi.org/10.1016/S1470-2045(16)30166-8)

Byeon HK, Na HJ, Yang YJ, Kwon HJ, Chang JW, Ban MJ, Kim WS, Shin DY, Lee EJ, Koh YW, et al. 2016 c-Met-mediated reactivation of PI3K/AKT signaling contributes to insensitivity of BRAF(V600E) mutant thyroid cancer to BRAF inhibition. Molecular Carcinogenesis 55 1678-1687. (https://doi.org/10.1002/mc.22418)

Byeon HK, Na HJ, Yang YJ, Ko S, Yoon SO, Ku M, Yang J, Kim JW, Ban MJ, Kim JH, et al. 2017 Acquired resistance to BRAF inhibition induces epithelial-to-mesenchymal transition in BRAF (V600E) mutant thyroid cancer by c-Met-mediated AKT activation. Oncotarget 8 596-609. (https://doi.org/10.18632/oncotarget.13480)

Chakravarty D, Santos E, Ryder M, Knauf JA, Liao XH, West BL, Bollag G, Kolesnick R, Thin TH, Rosen N, et al. 2011 Small-molecule MAPK inhibitors restore radioiodine incorporation in mouse thyroid cancers with conditional BRAF activation. Journal of Clinical Investigation 121 4700-4711. (https://doi.org/10.1172/JCI46382)

Challeton C, Branea F, Schlumberger M, Gaillard N, de Vathaire F, Badie C, Antonini P \& Parmentier C 1997 Characterization and radiosensitivity at high or low dose rate of four cell lines derived from human thyroid tumors. International Journal of Radiation Oncology, Biology, Physics $\mathbf{3 7}$ 163-169. (https://doi.org/10.1016/S0360-3016(96)00449-X)

Chapman PB, Hauschild A, Robert C, Haanen JB, Ascierto P, Larkin J, Dummer R, Garbe C, Testori A, Maio M, et al. 2011 Improved survival with vemurafenib in melanoma with BRAF V600E mutation. New England Journal of Medicine 364 2507-2516. (https://doi. org/10.1056/NEJMoa1103782)

Chow HY, Dong B, Duron SG, Campbell DA, Ong CC, Hoeflich KP, Chang LS, Welling DB, Yang ZJ \& Chernoff J 2015 Group I PAKs as therapeutic targets in NF2-deficient meningioma. Oncotarget 6 1981-1994. (https://doi.org/10.18632/oncotarget.2810)

Chow HY, Dong B, Valencia CA, Zeng CT, Koch JN, Prudnikova TY \& Chernoff J 2018 Group I PAKs are essential for epithelial-mesenchymal transition in an Apc-driven model of colorectal cancer. Nature Communications 9 3473. (https://doi.org/10.1038/s41467-018-05935-6)

Fabien N, Fusco A, Santoro M, Barbier Y, Dubois PM \& Paulin C 1994 Description of a human papillary thyroid carcinoma cell line. Morphologic study and expression of tumoral markers. Cancer $\mathbf{7 3}$ 
2206-2212. (https://doi.org/10.1002/1097-

0142(19940415)73:8<2206::AID-CNCR2820730828>3.0.CO;2-M)

Fagin JA \& Wells SA Jr 2016 Biologic and clinical perspectives on thyroid cancer. New England Journal of Medicine 375 1054-1067. (https://doi.org/10.1056/NEJMra1501993)

Falchook GS, Millward M, Hong D, Naing A, Piha-Paul S, Waguespack SG, Cabanillas ME, Sherman SI, Ma B, Curtis M, et al. 2015 BRAF inhibitor dabrafenib in patients with metastatic BRAFmutant thyroid cancer. Thyroid 25 71-77. (https://doi.org/10.1089/ thy.2014.0123)

Goretzki PE, Frilling A, Simon D \& Roeher HD 1990 Growth regulation of normal thyroids and thyroid tumors in man. Recent Results in Cancer Research 118 48-63. (https://doi.org/10.1007/978-3-64283816-3_6)

Goto H, Tanabe K, Manser E, Lim L, Yasui Y \& Inagaki M 2002 Phosphorylation and reorganization of vimentin by p21-activated kinase (PAK). Genes to Cells 7 91-97. (https://doi. org/10.1046/j.1356-9597.2001.00504.x)

Haraldsdottir S \& Shah MH 2014 An update on clinical trials of targeted therapies in thyroid cancer. Current Opinion in Oncology 26 36-44. (https://doi.org/10.1097/CCO.0000000000000029)

Harbron C 2010 A flexible unified approach to the analysis of preclinical combination studies. Statistics in Medicine 29 1746-1756. (https://doi.org/10.1002/sim.3916)

Hauschild A, Grob JJ, Demidov LV, Jouary T, Gutzmer R, Millward M, Rutkowski P, Blank CU, Miller WH Jr, Kaempgen E, et al. 2012 Dabrafenib in BRAF-mutated metastatic melanoma: a multicentre, open-label, phase 3 randomised controlled trial. Lancet 380 358-365. (https://doi.org/10.1016/S0140-6736(12)60868-X)

Heldin NE, Cvejic D, Smeds S \& Westermark B 1991 Coexpression of functionally active receptors for thyrotropin and platelet-derived growth factor in human thyroid carcinoma cells. Endocrinology 129 2187-2193. (https://doi.org/10.1210/endo-129-4-2187)

Higuchi M, Onishi K, Kikuchi C \& Gotoh Y 2008 Scaffolding function of PAK in the PDK1-Akt pathway. Nature Cell Biology 10 1356-1364. (https://doi.org/10.1038/ncb1795)

Ito T, Seyama T, Hayashi $\mathrm{Y}$, Hayashi T, Dohi K, Mizuno T, Iwamoto K, Tsuyama N, Nakamura N \& Akiyama M 1994 Establishment of 2 human thyroid-carcinoma cell-lines $(8305 \mathrm{c}, 8505 \mathrm{c})$ bearing p53 gene-mutations. International Journal of Oncology 4 583-586. (https:// doi.org/10.3892/ijo.4.3.583)

Joseph EW, Pratilas CA, Poulikakos PI, Tadi M, Wang W, Taylor BS, Halilovic E, Persaud Y, Xing F, Viale A, et al. 2010 The RAF inhibitor PLX4032 inhibits ERK signaling and tumor cell proliferation in a V600E BRAF-selective manner. PNAS 107 14903-14908. (https://doi. org/10.1073/pnas.1008990107)

Kissil JL, Johnson KC, Eckman MS \& Jacks T 2002 Merlin phosphorylation by p21-activated kinase 2 and effects of phosphorylation on merlin localization. Journal of Biological Chemistry 277 10394-10399. (https://doi.org/10.1074/jbc. M200083200)

Knauf JA, Luckett KA, Chen KY, Voza F, Socci ND, Ghossein R \& Fagin JA 2018 Hgf/Met activation mediates resistance to BRAF inhibition in murine anaplastic thyroid cancers. Journal of Clinical Investigation 128 4086-4097. (https://doi.org/10.1172/JCI120966)

Landa I, Pozdeyev N, Korch C, Marlow LA, Smallridge RC, Copland JA, Henderson YC, Lai SY, Clayman GL, Onoda N, et al. 2019 Comprehensive genetic characterization of human thyroid cancer cell lines: a validated panel for preclinical studies. Clinical Cancer Research 25 3141-3151. (https://doi.org/10.1158/1078-0432.CCR-18-2953)

Li F, Adam L, Vadlamudi RK, Zhou H, Sen S, Chernoff J, Mandal M \& Kumar R 2002 P21-activated kinase 1 interacts with and phosphorylates histone $\mathrm{H} 3$ in breast cancer cells. EMBO Reports 3 767-773. (https://doi.org/10.1093/embo-reports/kvf157)

Liu D, Hou P, Liu Z, Wu G \& Xing M 2009 Genetic alterations in the phosphoinositide 3-kinase/Akt signaling pathway confer sensitivity of thyroid cancer cells to therapeutic targeting of Akt and mammalian target of rapamycin. Cancer Research 69 7311-7319. (https://doi.org/10.1158/0008-5472.CAN-09-1077)

Liu R, Liu D, Trink E, Bojdani E, Ning G \& Xing M 2011 The Aktspecific inhibitor MK2206 selectively inhibits thyroid cancer cells harboring mutations that can activate the PI3K/Akt pathway. Journal of Clinical Endocrinology and Metabolism 96 E577-E585. (https://doi. org/10.1210/jc.2010-2644)

Loewe S 1953 The problem of synergism and antagonism of combined drugs. Arzneimittel-Forschung 3 285-290.

Lu H, Liu S, Zhang G, Bin W, Zhu Y, Frederick DT, Hu Y, Zhong W, Randell S, Sadek N, et al. 2017 PAK signalling drives acquired drug resistance to MAPK inhibitors in BRAF-mutant melanomas. Nature 550 133-136. (https://doi.org/10.1038/nature24040)

Manser E, Leung T, Salihuddin H, Zhao ZS \& Lim L 1994 A brain serine/ threonine protein kinase activated by Cdc42 and Rac1. Nature 367 40-46. (https://doi.org/10.1038/367040a0)

Marlow LA, D'Innocenzi J, Zhang Y, Rohl SD, Cooper SJ, Sebo T, Grant C, McIver B, Kasperbauer JL, Wadsworth JT, et al. 2010 Detailed molecular fingerprinting of four new anaplastic thyroid carcinoma cell lines and their use for verification of RhoB as a molecular therapeutic target. Journal of Clinical Endocrinology and Metabolism 95 5338-5347. (https://doi.org/10.1210/jc.2010-1421)

Maroto B, Ye MB, von Lohneysen K, Schnelzer A \& Knaus UG 2008 P21activated kinase is required for mitotic progression and regulates Plk1. Oncogene 27 4900-4908. (https://doi.org/10.1038/ onc.2008.131)

McCarty SK, Saji M, Zhang X, Jarjoura D, Fusco A, Vasko VV \& Ringel MD 2010 Group I p21-activated kinases regulate thyroid cancer cell migration and are overexpressed and activated in thyroid cancer invasion. Endocrine-Related Cancer 17 989-999. (https://doi. org/10.1677/ERC-10-0168)

McCarty SK, Saji M, Zhang X, Knippler CM, Kirschner LS, Fernandez S \& Ringel MD 2014 BRAF activates and physically interacts with PAK to regulate cell motility. Endocrine-Related Cancer 21 865-877. (https://doi.org/10.1530/ERC-14-0424)

Montero-Conde C, Ruiz-Llorente S, Dominguez JM, Knauf JA, Viale A, Sherman EJ, Ryder M, Ghossein RA, Rosen N \& Fagin JA 2013 Relief of feedback inhibition of HER3 transcription by RAF and MEK inhibitors attenuates their antitumor effects in BRAF-mutant thyroid carcinomas. Cancer Discovery 3 520-533. (https://doi. org/10.1158/2159-8290.CD-12-0531)

Nayal A, Webb DJ, Brown CM, Schaefer EM, Vicente-Manzanares M \& Horwitz AR 2006 Paxillin phosphorylation at Ser273 localizes a GIT1-PIX-PAK complex and regulates adhesion and protrusion dynamics. Journal of Cell Biology 173 587-589. (https://doi. org $/ 10.1083 /$ jcb.200509075)

Nazarov M, Goeyvaerts N \& Harbron C 2018. drugCombo: Drug Interaction Modeling Based on Loewe Additivity Following Harbron's Approach. R package edn 1.0.2. (available at: https://CRAN.R-project. org/package= drugCombo)

Ndubaku CO, Crawford JJ, Drobnick J, Aliagas I, Campbell D, Dong P, Dornan LM, Duron S, Epler J, Gazzard L, et al. 2015 Design of selective PAK1 inhibitor G-5555: improving properties by employing an unorthodox low-pK a polar moiety. ACS Medicinal Chemistry Letters 6 1241-1246. (https://doi.org/10.1021/ acsmedchemlett.5b00398)

Noone AM, Howlader N, Krapcho M, Miller D, Brest A, Yu M, Ruhl J, Tatalovich Z, Mariotto A, Lewis DR, et al. 2018 SEER Cancer Statistics Review, 1975-2015, based on November 2017 SEER data submission, posted to the SEER web site, April 2018. Bethesda, MD, USA: National Cancer Institute. (available at: https://seer.cancer.gov/ archive/csr/1975_2015/)

Ofir Dovrat T, Sokol E, Frampton G, Shachar E, Pelles S, Geva R \& Wolf I 2018 Unusually long-term responses to vemurafenib in BRAF V600E mutated colon and thyroid cancers followed by the development of https://erc.bioscientifica.com

https://doi.org/10.1530/ERC-19-0188 (c) 2019 Society for Endocrinology Published by Bioscientifica Ltd. Printed in Great Britain 
rare RAS activating mutations. Cancer Biology and Therapy 19 871-874. (https://doi.org/10.1080/15384047.2018.1480289)

Ong CC, Jubb AM, Jakubiak D, Zhou W, Rudolph J, Haverty PM, Kowanetz M, Yan Y, Tremayne J, Lisle R, et al. 2013 P21-activated kinase 1 (PAK1) as a therapeutic target in BRAF wild-type melanoma. Journal of the National Cancer Institute 105 606-607. (https://doi. org/10.1093/jnci/djt054)

Ong CC, Gierke S, Pitt C, Sagolla M, Cheng CK, Zhou W, Jubb AM, Strickland L, Schmidt M, Duron SG, et al. 2015 Small molecule inhibition of group I p21-activated kinases in breast cancer induces apoptosis and potentiates the activity of microtubule stabilizing agents. Breast Cancer Research 17 59. (https://doi.org/10.1186/s13058015-0564-5)

Poulikakos PI, Zhang C, Bollag G, Shokat KM \& Rosen N 2010 RAF inhibitors transactivate RAF dimers and ERK signalling in cells with wild-type BRAF. Nature 464 427-430. (https://doi.org/10.1038/ nature08902)

Radu M, Semenova G, Kosoff R \& Chernoff J 2014 PAK signalling during the development and progression of cancer. Nature Reviews: Cancer 14 13-25. (https://doi.org/10.1038/nrc3645)

Rudolph J, Murray LJ, Ndubaku CO, O'Brien T, Blackwood E, Wang W, Aliagas I, Gazzard L, Crawford JJ, Drobnick J, et al. 2016 Chemically diverse group I P21-activated kinase (PAK) inhibitors impart acute cardiovascular toxicity with a narrow therapeutic window. Journal of Medicinal Chemistry 59 5520-5541. (https://doi.org/10.1021/acs. jmedchem.6b00638)

Semenova G \& Chernoff J 2017 Targeting PAK1. Biochemical Society Transactions 45 79-88. (https://doi.org/10.1042/BST20160134)

Shinohara M, Chung YJ, Saji M \& Ringel MD 2007 AKT in thyroid tumorigenesis and progression. Endocrinology 148 942-947. (https:// doi.org/10.1210/en.2006-0937)

Shrestha Y, Schafer EJ, Boehm JS, Thomas SR, He F, Du J, Wang S, Barretina J, Weir BA, Zhao JJ, et al. 2012 PAK1 is a breast cancer oncogene that coordinately activates MAPK and MET signaling. Oncogene 31 3397-3408. (https://doi.org/10.1038/onc.2011.515)

Tanaka J, Ogura T, Sato H \& Hatano M 1987 Establishment and biological characterization of an in vitro human cytomegalovirus latency model. Virology 161 62-72. (https://doi.org/10.1016/00426822(87)90171-1)
Tang DD, Bai Y \& Gunst SJ 2005 Silencing of p21-activated kinase attenuates vimentin phosphorylation on Ser-56 and reorientation of the vimentin network during stimulation of smooth muscle cells by 5-hydroxytryptamine. Biochemical Journal 388 773-783. (https://doi. org/10.1042/BJ20050065)

Vasko V, Espinosa AV, Scouten W, He H, Auer H, Liyanarachchi S, Larin A, Savchenko V, Francis GL, de la Chapelle A, et al. 2007 Gene expression and functional evidence of epithelial-to-mesenchymal transition in papillary thyroid carcinoma invasion. PNAS $\mathbf{1 0 4}$ 2803-2808. (https://doi.org/10.1073/pnas.0610733104)

Wang Z, Fu M, Wang L, Liu J, Li Y, Brakebusch C \& Mei Q 2013 P21activated kinase 1 (PAK1) can promote ERK activation in a kinaseindependent manner. Journal of Biological Chemistry $\mathbf{2 8 8}$ 20093-20099. (https://doi.org/10.1074/jbc.M112.426023)

Watson IR, Li L, Cabeceiras PK, Mahdavi M, Gutschner T, Genovese G, Wang G, Fang Z, Tepper JM, Stemke-Hale K, et al. 2014 The RAC1 P29S hotspot mutation in melanoma confers resistance to pharmacological inhibition of RAF. Cancer Research 74 4845-4852. (https://doi.org/10.1158/0008-5472.CAN-14-1232-T)

Xiao GH, Beeser A, Chernoff J \& Testa JR 2002 P21-activated kinase links Rac/Cdc42 signaling to merlin. Journal of Biological Chemistry 277 883-886. (https://doi.org/10.1074/jbc.C100553200)

Xing M 2010 Genetic alterations in the phosphatidylinositol-3 kinase/ Akt pathway in thyroid cancer. Thyroid 20 697-706. (https://doi. org/10.1089/thy.2010.1646)

Xing J, Liu R, Xing M \& Trink B 2011 The BRAFT1799A mutation confers sensitivity of thyroid cancer cells to the BRAFV600E inhibitor PLX4032 (RG7204). Biochemical and Biophysical Research Communications 404 958-962. (https://doi.org/10.1016/j.bbrc.2010.12.088)

Xu X, Quiros RM, Gattuso P, Ain KB \& Prinz RA 2003 High prevalence of BRAF gene mutation in papillary thyroid carcinomas and thyroid tumor cell lines. Cancer Research 63 4561-4567.

Zhao ZS, Lim JP, Ng YW, Lim L \& Manser E 2005 The GIT-associated kinase PAK targets to the centrosome and regulates Aurora-A. Molecular Cell 20 237-249. (https://doi.org/10.1016/j. molcel.2005.08.035)

Zhao W, Zhang L, Zeng L \& Yang H 2012 A two-stage response surface approach to modeling drug interaction. Statistics in Biopharmaceutical Research 4 375-383. (https://doi.org/10.1080/19466315.2012.707087)

Received in final form 28 May 2019

Accepted 30 May 2019

Accepted Preprint published online 30 May 2019
C) 2019 Society for Endocrinology Published by Bioscientifica Ltd. Printed in Great Britain 